\title{
Assessment of Healthcare Professional's Knowledge, Skills, Motivation, and Commitment to Clinical Pathways Implementation
}

\author{
Ivana Alona ${ }^{1,2} \mathbb{D}$, Juliandi Harahap ${ }^{2 *} \mathbb{D}$, Andike Aribi $^{1} \mathbb{D}$, Riyadh Ikhsan $^{1,3} \mathbb{D}$, Muhammad. Iqbal Rizki Siregar $^{1}(\mathbb{D}$ \\ ${ }^{1}$ Department of Medical Services, Universitas Sumatera Utara Hospital, Universitas Sumatera Utara, Medan, Indonesia; \\ ${ }^{2}$ Department of Community Medicine, Faculty of Medicine, Universitas Sumatera Utara, Medan, Indonesia; ${ }^{3}$ Department of \\ Dermatology and Venereology, Faculty of Medicine, Universitas Sumatera Utara, Medan, Indonesia
}

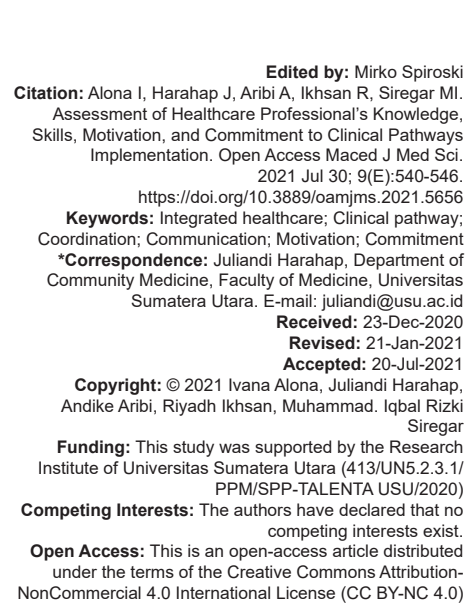

Introduction

Nowadays, healthcare providers face substantial challenges such as the introduction of a diagnosis-related group system (DRGs), patients' right to freedom of choice, high standard of care demands, patient satisfaction, and health workforce dynamics [1]. They often juggled providing quality healthcare and efficiently deliver costeffective care. An assistive approach is required to deliver an acceptable minimum standard service as a cliniciandirected diagnostic and therapeutic plan. This approach should reduce clinical variations, improve care quality, and keep care delivery at a minimum length of stay [2].

Clinical pathways (CPs) can be used as tool to guide evidence-based healthcare [3]. It reserves an integrated service plan to deliver clinical processes, interventions, and treatments with measurable outcomes in a timely fashion [4]. The implementation is carried out as a collaborative guideline for a plan, coordination, delivery, monitoring, documentation of care [2], enhances critical thinking, provides optimal clinical outcomes, and saves costs [5], [6].
CPs can increase patient and family satisfaction because of the predicted treatment and process. It can improve interprofessional communication and cooperation between medical teams, which in turn increase job satisfaction. A study stated that the implementation of CPs increased doctor's satisfaction scores because of the uniformity of care management. On the contrary, the satisfaction scores of nurses were in contrast. A CP is more than just a document targeting efficiency and it is also a complex and multicomponent intervention [7].

\section{CP implementation in USU Hospital}

\section{context}

In 2016, USU Hospital evaluated the implementation of $15 \mathrm{CPs}$. The CPs were initially developed based on the recommendations of the Medical Staff Group (KSM) and integrated with medical, nursing, pharmaceutical, and nutritional care. However, according to the report of the USU Hospital Quality sub-audit Medical Committee, the implementation of these CPs was generally inadequate. Numerous variants and only a few cases related to the CP process were documented. 
Before the current study, an intervention such as dengue hemorrhagic fever Grade 1 and 2 CP socialization was carried out in USU Hospital. As a result, it was found that the socialization improved the adherence of treatments, decreased treatment, laboratory costs, and length of treatment days, but adherence to the mandatory tests was not different [8]. It was suggested that socialization intervention only was not sufficient to achieve organizational goals. CPs will not be successfully implemented if it is not accompanied by the readiness of the hospital as an organization, implementers, and medical personnel who are specifically involved and play roles in the CPs implementation [9].

Health system inputs are essential to delivering optimal health services [10]. Equipping the system with optimal resources, including human resources, is a vital source for systemization. Furthermore, the introduction of innovative processes or procedures into service delivery will, in turn, improve the performance and outcomes of quality, access, and efficiency. Thus, gaps of knowledge, skills, and processes between the resource's availability and necessity are essential to respond to health demand [11].

This study aims to assess healthcare professionals' knowledge, skills, motivation, and commitment to CPs implementation in USU Hospital.

\section{Materials and Methods}

\section{Study design and setting}

This research is a descriptive, cross-sectional study, which was conducted from July-September 2020. This study was carried out in USU Hospital. USU Hospital is a teaching Hospital in Medan province, Indonesia. It was accredited by the Indonesian National Hospital Accreditation (Komisi Akreditasi Rumah Sakit/ KARS) in 2016 and 2019. The hospital provides the National Health Insurance System, which engages reimbursement claims based on the packages system called Indonesia Case-Based Groups (INACBGs).

\section{Study population and sampling}

The population of this study was healthcare professionals in USU Hospital, including clinicians, nurses, and pharmacists. We used quota sampling by $20 \%$ of each healthcare professional group in the hospital. The participants involved ten clinicians, fifty nurses, and five pharmacists.

\section{Study tool}

We created and developed a structured questionnaire, then tested it on 30 participants for validity and reliability. We used Pearson correlation with $p<0.05$ or $r>0.5$ for valid questions and Cronbach's Alpha $>0.6$ for reliability of the questionnaire. As the result, we had 29 valid and reliable questions which consist of 10 questions for knowledge, 8 questions for skill, 5 questions for motivation, and 6 questions for commitment. This questionnaire was delivered online via Google form to participants and collected then input in SPSS version 22.

\section{Statistical method}

Descriptive data regarding participant characteristics, category levels of knowledge, skills, motivation, and commitment were obtained and presented in a frequency distribution table. We also analyzed correlations among scores of the variables using the Pearson correlation with $p<0.05$.

\section{Ethics}

This study was approved by the Research Ethics Commission of the Universitas Sumatera Utara (approval number 371/KEP/USU/2020). Written informed consent was obtained from each participant before data collection.

\section{Results}

We surveyed 10 doctors, 50 nurses, and 5 pharmacists regarding CPs implementation in USU Hospital. The survey included information about the participant's characteristics consisting of age, education level, length of working as their current profession, length of working at USU Hospital, and working areas. We also obtained knowledge, skills, motivation, and commitment score on CP implementation from the survey. Besides, we correlated among the variables to see the relationship with each variable.

\section{Healthcare professional characteristics involved in $\mathrm{CP}$ implementation}

Based on Table 1, most of the participants in this study were in the age range of 31-40 years (56.9\%). Most of the participants' education level was of bachelor's degree (52.3\%). The majority of participants' length of working as their current profession was in the range of $6-10$ years $(55.4 \%)$. Dominantly, their length of working at USU Hospital was in between 2 and 4 years $(36.9 \%)$. Most of the participants came from ward class $3(26.2 \%)$. 
Table 1: Characteristics of healthcare professionals involved in the implementation of the CP in USU Hospital

\begin{tabular}{lll}
\hline Characteristics & Frequency (person) $\mathrm{n}=65$ & Percentage \\
\hline Age (years) & 25 & \\
$21-30$ & 37 & 38.5 \\
$31-40$ & 2 & 56.9 \\
$41-50$ & 1 & 3.1 \\
>50 & & 1.5 \\
Education level & 19 & \\
Diploma & 34 & 29.2 \\
Bachelor degree & 10 & 52.3 \\
Specialists & 2 & 15.4 \\
Magister & & 3.1 \\
Profession & 10 & \\
Doctor & 50 & 15.4 \\
Nurse & 5 & 76.9 \\
Pharmacist & & 7.7 \\
Length of working (years) & 16 & \\
1-5 & 36 & 24.6 \\
6-10 & 7 & 55.4 \\
11-15 & 6 & 10.8 \\
16-20 & 11 & 9.2 \\
Length of working in USU Hospital (years) & \\
<2 & 24 & 16.9 \\
2-4 & 11 & 36.9 \\
5-7 & 19 & 16.9 \\
8-10 & & 29.2 \\
Working areas & 3 & \\
VIP ward & 11 & 4.6 \\
Class 1 ward & 7 & 16.9 \\
Class 2 ward & 17 & 10.8 \\
Class 3 ward & 12 & 26.2 \\
Pediatric ward & 5 & 18.5 \\
Pharmacy unit & 10 & 7.7 \\
Medical staff group & & 15.4 \\
\hline
\end{tabular}

Healthcare professional's knowledge, skills, motivation, and commitment to CPs implementation

In this study, the participant's knowledge was measured by asking health workers' understanding of the meaning, elements, undertaken activities, other involved health workers, and the use of the CPs. There were ten questions in this aspect with the right or wrong answer. Based on Table 2, the participants' knowledge about CPs was generally high, with a percentage of $76.9 \%$, and none of them were categorized as low. By profession, $80 \%$ of doctors, $78 \%$ of nurses, and $60 \%$ of pharmacy officers had a high level of knowledge about CP implementation.

Table 2: The level of knowledge, skills, motivation, and commitment to CPs implementation among healthcare professionals in USU Hospital

\begin{tabular}{|c|c|c|c|c|c|}
\hline $\begin{array}{l}\text { Measured variables on } \\
\mathrm{CP} \text { implementation }\end{array}$ & $\begin{array}{l}\text { Frequency } \\
\text { (person) (n) }\end{array}$ & $\%$ & $\begin{array}{l}\text { Doctors } \\
\mathrm{n}(\%) \\
\end{array}$ & $\begin{array}{l}\text { Nurses } \\
\mathrm{n}(\%) \\
\end{array}$ & $\begin{array}{l}\text { Pharmacists } \\
\mathrm{n}(\%) \\
\end{array}$ \\
\hline \multicolumn{6}{|l|}{ Knowledge } \\
\hline Low & 0 & 0 & $0(0)$ & $0(0)$ & $0(0)$ \\
\hline Moderate & 15 & 23.1 & $2(20)$ & $11(22)$ & $2(40)$ \\
\hline High & 50 & 76.9 & $8(80)$ & $39(78)$ & $3(60)$ \\
\hline \multicolumn{6}{|l|}{ Skills } \\
\hline Low & 7 & 10.8 & $2(20)$ & $3(6)$ & $2(40)$ \\
\hline Moderate & 33 & 50.8 & $8(80)$ & $22(44)$ & $3(60)$ \\
\hline High & 25 & 38.5 & $0(0)$ & $25(50)$ & $0(0)$ \\
\hline \multicolumn{6}{|l|}{ Motivation } \\
\hline Low & 1 & 1.5 & $1(10)$ & $0(0)$ & $0(0)$ \\
\hline Moderate & 17 & 26.2 & $4(40)$ & $12(24)$ & $1(20)$ \\
\hline High & 47 & 72.3 & $5(50)$ & $38(76)$ & $4(80)$ \\
\hline \multicolumn{6}{|l|}{ Commitment } \\
\hline Low & 0 & 0 & $0(0)$ & $0(0)$ & $0(0)$ \\
\hline Moderate & 5 & 7.7 & $0(0)$ & $5(10)$ & $0(0)$ \\
\hline High & 60 & 92.3 & $10(100)$ & $45(90)$ & $5(100)$ \\
\hline
\end{tabular}

Skill aspects involved in the questionnaire were coordination and communication between caregivers or hospital management and the accuracy of the process when the CP form was available. In Table 2, it was mentioned that the participant's skill level in applying the $\mathrm{CP}$ was generally moderate, with a percentage of
$50.8 \%$. The skill level of the doctor and pharmacists were moderate, with the proportion of $80 \%$ and $60 \%$ within their profession, respectively, and none of them were in the high category. Meanwhile, among nurses, the skill level was dominantly high (50\%).

The motivational variables referred to in this study are motivated behavior in implementation, such as optimism in implementing CPs, passion in completing the $\mathrm{CP}$ form, and enthusiasm in participating in the $\mathrm{CP}$ activity process. Based on Table 2, the motivation level of healthcare professionals implementing CPs in this study was generally high, with a percentage of $72.3 \%$. The high motivation level within the profession of doctors, nurses, and pharmacy were with percentages of $50 \%, 76 \%$, and $80 \%$, respectively. Ten percent of doctors had low motivation, but none were in the low motivation category among nurses and pharmacists.

In this study, the commitment variable is about health worker's willingness to carry out the $\mathrm{CP}$ activity process, filling out $\mathrm{CP}$ forms, and coordinating with the team and management. According to Table 2, the level of commitment to implementing the CPs in USU Hospital was high $(92.3 \%)$ and none was in a low category. The percentage of doctors, nurses, and pharmacy officers who had high commitment is $100 \%, 90 \%$, and $100 \%$.

\section{The relationship among measured variables on $\mathrm{CP}$ implementation}

In this study, we analyzed the relationship between the measured variables of knowledge, skills, motivation, and commitment (Table 3). Pearson correlation coefficient was calculated between two variables' scores. We found positive correlations with different levels of strength $(p<0.05)$ among the measured variables. There was very low correlation between knowledge and skills $(r=0.257)$; low correlation between motivation and skills $(r=0.390)$ and commitment and skills $(r=0.394)$; and sufficient correlation between motivation and commitment $(r=0.640)$ on CP implementation.

Table 3: Correlation tests among variables of knowledge, skills, motivation, and commitment to CP implementation

\begin{tabular}{lll}
\hline Relationship among variables & Coefficient $(r)$ & P-value \\
Knowledge and skills & $0.257^{*}$ & 0.039 \\
Knowledge and motivation & -0.004 & 0.973 \\
Knowledge and commitment & 0.153 & 0.223 \\
Motivation and skills & $0.390^{\star *}$ & 0.001 \\
Commitment and skills & $0.394^{* *}$ & 0.001 \\
Motivation and commitment & $0.640^{\star *}$ & 0.001 \\
\hline
\end{tabular}

\section{Discussion}

Healthcare professional's knowledge of $\mathrm{CP}$ implementation varies in many studies. From this study, it is known that doctors, nurses, and pharmacists at 
USU Hospital have good knowledge about CP in the hospital. Similarly, CP research conducted by Balbeid et al. found that most dentists in their study had good knowledge regarding $\mathrm{CP}$ implementation, while the nurses' knowledge in their study was enough [12]. In comparison, a study regarding typhoid $\mathrm{CP}$ in a hospital in Indonesia stated that the healthcare personnel's level of knowledge in their hospital was moderate [9]. Knowledge contributes to the employee's performance of the organization, which starts through the individual aspect [13], [14].

Evidence-practice gaps remain a challenge for health services [15], [16], [17], [18], [19], [20], [21]. At USU Hospital, the CP implementation skills of communication and coordination are moderate. Several studies have shown that poor communication, coordination, collaboration, and ineffective teamwork will cause negative impacts on staff relationships, staff satisfaction and turnover, and patient outcomes [22]. According to Jabbour, an integrated pathway requires complex interventions due to interprofessional and hospital practices or habits [23]. Many healthcare professionals are used to poor communication and teamwork skills due to a culture of low expectations that have grown in health care settings [24].

Changes in the habitual practice of health workers need to be changed by finding effective strategies so that coordination and communication between health workers or hospital management and the accuracy process in the CPs can take place adequately. Then, the strategies must be transformed into a culture in the hospital. Continuous change, enabling distributive and inclusive leadership to support the change process and inspire people to work according to the shared goals and create narratives and a sense of purpose are attributable to change and transform values, culture, and behavior [25]. Leaders in both medicine and nursing have issued ongoing initiatives to develop a cooperative rather than a competitive agenda to benefit patient care. A strong encouragement for successful teamwork among healthcare professionals to implement CPs successfully can be developed by drawing team attention to measurable improvements for the patients they serve together.

In this study, generally, healthcare professionals at USU Hospital were well-motivated in implementing CPs. However, $10 \%$ of the doctors had low motivation, and $40 \%$ had a moderate one. Doctors are the leader of patient care in a hospital. Therefore, their attitudes and motivation toward CPs are essential in the implementation [26]. According to a study, a professional individual who is motivated and has good intentions is not enough if the working team is not sufficient or interested in implementing CP [27]. Thus, increasing the multidiscipline healthcare professional motivation at a similar stage will contribute to the optimum CP implementation process. According to a study (Dirgagunarsa, 1996), motivated behavior can be created as behind-the-scenes behavior by existing needs and is directed toward achieving goals, therefore, needs must be met, and desires can be satisfied [28].

Astudy stated thatmotivation is acquired through rewards, either intrinsic or external to the activity, and its achievement is enabled by activity performance [29]. Intrinsic rewards are associated with job issues such as accomplishment, authority, diversity, responsibility, and personal and professional growth. The intrinsic motivation tools can be status, acknowledgment, acclamation from superiors and partners, personal satisfaction, and self-confidence [30]. External motivators include an exchange of compensation that is taken for the activity performed for the attainment of people's value [29]. The tools of the external motivation comprise pay, fringe benefits, job security, promotions, private office space, and social climate. In addition, they include competitive salaries, raised pay, bonuses, and indirect form of payments [30]. The literature suggests that healthcare professionals who are motivated by intrinsic and extrinsic motivators and highly committed will do their best to accomplish their job [31]. This study suggested those intrinsic and extrinsic rewards can be adopted to meet the doctors' need and desire to increase their motivation for CPs implementation.

Healthcare professionals' commitment to the implementation of the CPs in USU Hospital was high. However, this study recommends that the hospital organization maintain their willingness to ensure the continuance of CPs implementation by improving their organizational commitment. Organizational commitment is the desire of the organization members to maintain their membership and willingness to survive in achieving results based on organizational goals [32].

From this study, motivation and commitment score have a substantial positive relationship in the CPs implementation. According to a study, the higher the employee's organizational commitment, the better work motivation, and the better performance that are beneficial to the organization [33]. The employees' productivity is highly associated with their motivation levels and a higher level of organizational commitment [31]. In organizational psychology, commitment and motivation generally alter independently to a certain extent [34]. Commitment is a motivational phenomenon that is related to motivation based variables [35]. Researchers also suppose that committed employees provide contributions to the organization in terms of motivation [35], [36], [37], [38]. Furthermore, committed organizations that give attention to increased employee job satisfaction, motivation, and morale may bring long-term impacts to the company's success, such as loyalty, productivity, and employee retention [39]. Retention, attendance, motivation, and job productivity are positive impacts of organizational commitment [34], [36], [37], [39], [40], [41].

Organizational commitment is essential to achieve higher quality health care services and is linked 
to job satisfaction among providers [42]. There are three types of organizational commitment (i) affective, (ii) continuance, and (iii) normative commitment. Affective commitment relates to an employee's emotional attachment to the organization and its goals. Employees with more affective commitment are found to be motivated to higher levels of performance and make more meaningful contributions than employees who express continuance or normative commitment. Thus, affective commitment should be developed for the meaningful teamwork motivation to deliver appropriate process in CPs implementation.

Affective commitment involves a strong belief and acceptance of values and goals, a willingness to add more efforts, and a desire to stay as part of the organization. There are several literatures that predict the affective commitment of an organization [43], [44], [45]. A study proposes that employees' motivation to remain on the job is a significant predictor of affective commitment [46]. Individual willingness to make extra efforts for the organization is also another predictor of affective commitment. On the other hand, a monotonous or uninteresting job decreases motivation and prevents the acceptance of organizational values and goals [47]. In addition, an accumulation of overwork load or task intensification will dampen personal performance and bring a negative impact on affective commitment [48]. Furthermore, social supports such as a pleasant coworkers and a pleasant supervisor is considered to bring positive affective commitment [46]. However, this study did not take into account the context of the relationship of affective commitment aspects among the individual, group of healthcare professionals, or organizational levels in CPs implementation. Further study will provide beneficial outputs for a sustainable CPs implementation to healthcare providers.

CPs goals cannot be achieved if it is not well implemented [49]. According to some studies, attitudes and lack of motivation are two reasons that healthcare professionals do not apply CPs [50], [51], [52]. USU hospital should demonstrate the benefit of CP implementation to ensure the healthcare professionals in their setting develop positive attitudes toward CP implementation. Furthermore, teamwork motivation for social support is essential to build affective commitment, in addition to a pleasant supervisor. If the team members of the organization have positive contact with their supervisor, the team will be willing to make extra efforts for their job done [46]. A study recommends dissemination, education and training, social interaction, and decision-support systems as successful strategies to increase teamwork motivation [53].

However, the organization should note that CPs implementation required a number of resources once it is recommended as an active process [3]. An active process requires maximum healthcare inputs and supports from managers and healthcare professionals to remove associated resistance from the CPs implementation.
This process should include team implementation and "local champions," identify barriers to change or local evidence-practice gaps, team readiness to change in CP development, adaptation of evidence to the local circumstances, staff education sessions, incorporation of reminder system, and audit and feedback on the CP compliance [54], [55], [56], [57], [58]. Prioritization of CP development in certain areas is necessary to consider, given the constraints of the resource capacity of the organization [59].

\section{Conclusion}

We concluded that healthcare professional's knowledge, motivation, and commitment on CPs implementation in this hospital were adequate. However, skills of coordination and communication on CPs implementation between healthcare professionals were moderate. The study found significant relationship between the measured variables of knowledge, skills, motivation, and commitment at different levels of strength $(p<0.05)$ where there were very low correlation between knowledge and skills, low correlation between motivation and skills, low correlation between commitment and skills, and strong correlation between motivation and commitment on CPs implementation. Therefore the skill aspects should be improved, because this may result as evidence-practice gaps in health services and failure in CPs implementation.

\section{References}

1. Ronellenfitsch U, Rossner E, Jakob J, Post S, Hohenberger P, Schwarzbach M. Clinical pathways in surgery should we introduce them into clinical routine? A review article. Langenbecks Arch Surg. 2008;393(4):449-57. https://doi. org/10.1007/s00423-008-0303-9

PMid:18297305

2. Cheah, J. Development and implementatiton of a clinical pathway programme in an acute care general hospital in Singapore. Int J Qual Health Care. 2000;12(5):403-12. https:// doi.org/10.1093/intqhc/12.5.403

PMid:11079220

3. Rotter $\mathrm{T}$, de Jong RB, Lacko SE, Ronellenfitsch $U$, and Kinsman L. Clinical pathways as a quality strategy. In: Busse R, Klazinga N, Panteli D, Quentin W, editors. Improving Healthcare Quality in Europe:Characteristics, Effectiveness and Implementation of Different Strategies. Copenhagen, Denmark: European Observatory on Health Systems and Policies; 2019. https://doi.org/10.1787/b11a6e8f-en

4. Firmanda D. Panduan Manajemen Risiko Klinisdan Keamanan/ Keselamatan Pasien (Clinical Risks Management and Patient Safety). Jakarta: KomiteMedik RS Fatmawati; 2005.

5. Holloway NM. Medical Surgical Care Planning. Orinda, California: Lippincott Williams and Wilkins; 2004. 
6. Rotter T, Kinsman L, James EL, Machotta A, Gothe H, Willis $\mathrm{S}$, et al. Clinical pathways: Effects on professional practice, patient outcomes, length of stay and hospital costs. Cochrane Database Syst Rev. 2010;3:CD006632. https://doi.org/10.1002/14651858. cd006632 PMid:20238347

7. Sung KH, Chung, CY, Lee KM, Lee SY, Ahn S, Park S, et al. Application of clinical pathway using electronic medical record system pediatric patients with supracondylar fracture of the humerus: $A$ before and after comparative study. BMC Med Inform Decis Mak. 2013;13:87. https://doi. org/10.1186/1472-6947-13-87

PMid:23938025

8. Alona I, Harahap J, Aribi A. A Quasi-Experimental Study of Dengue Hemorhagic Fever Grade 1 and 2 Clinical Pathway Implementation in Universitas Sumatera Utara Hospital, North Sumatera, Indonesia. The $3^{\text {rd }}$ International Conference Community Research and Service Engagements (IC2RSE) Proceeding Book. EAl; 2000. https://doi.org/10.4108/ eai.4-12-2019.2293799

9. Dewi P, Sandra C, Witcahyo E. Resources required in clinical pathway for typhoid fever treatment at kaliwates genneral hospital in 2017. J Adm Kesehatan Indones. 2019;7(2):155-61. https://doi.org/10.20473/jaki.v7i2.2019.155-161

10. Azwar A. Pengantar Administrasi Kesehata. $3^{\text {rd }}$ ed. Jakarta: Jakarta Binarupa Aksara; 2010.

11. World Health Organization. Health Services Delivery: A Concept Note. Health Services Delivery Programme WHO Regional Office for Europe. Geneva: World Health Organization; 2015.

12. Balbeid M, Rachmi A, Alamsyah A. Pengaruh pengetahuan dan sikap dokter dan perawat terhadap kesiapan berubah dalam menerapkan clinical pathway. E-Prodent J Dent 2018;2:98-107. https://doi.org/10.21776/ub.eprodenta.2018.002.01.1

13. Suhartini $Y$. Faktor-faktor yang mempengaruhi minat mahasiswa dalam berwiraswasta (studi pada mahasiswa universitas PGRI Yogyakarta). J Akmen UPY. 2011;7:38-59. https://doi. org/10.22225/jraw.1.2.1838.37-45

14. Kuncoro M. Mudah Memahami dan Menganalisis Indikator Ekonomi. Yogyakarta: UPP STIM YKPN; 2013.

15. Graham ID, Logan J, Harrison MB, Straus SE, Tetroe J, Caswell W, et al. Lost in knowledge translation: Time for a map? J Contin Educ Heal Prof 2006;26(1):13-24. https://doi. org/10.1002/chp.47

PMid:16557505

16. McGlynn EA, Asch SM, Adams J, Keesey J, Hicks A DeCristofaro $A$, et al. The quality of health care delivered to adults in the United States. N Engl J Med. 2003;348(26):263545. https://doi.org/10.1056/nejmsa022615 PMid:12826639

17. Huckson S, Davies J. Closing evidence to practice gaps in emergency care: The Australian experience. Acad Emerg Med. 2007;14(11):1058-63. https://doi.org/10.1197/j. aem.2007.06.015 PMid: 17704351

18. Seddon ME, Marshall MN, Campbell SM, Roland MO Systematic review of studies of quality of clinical care in general practice in the UK, Australia and New Zealand. Qual Health Care. 2001;10(3):152-8. https://doi.org/10.1136/qhc.0100152 PMid:11533422

19. Lougheed MD, Garvey N, Chapman KR, Cicutto L, Dales R, Day $A G$, et al. The Ontario asthma regional variation study: Emergency department visit rates and the relation to hospitalization rates. Chest. 2006;129(4):909-17. https://doi. org/10.1378/chest.129.4.909

PMid:16608938
20. Freedman SB, Gouin S, Bhatt M, Black KJ, Johnson D, Guimont C, et al. Pediatric emergency research Canada: prospective assessment of practice pattern variations in the treatment of pediatric gastroenteritis. Pediatrics. 2011;127(2):e287-95. https://doi.org/10.1542/peds.2010-2214 PMid:21262881

21. Goodman DC. Unwarranted variation in pediatric medimedical care. Pediatr Clin North Am. 2009;56(4):745-55. PMid:19660625

22. Rosentain A, O' Daniel M. Disruptive behaviour and clinical outcomes: Perceptions of nurses and physicians. Am J Nurs. 2005;105(1):54-64.

PMid:15659998

23. Jabbour M, Curran J, Scott SD, Guttman A, Rotter T, Ducharme $\mathrm{FM}$, et al. Best strategies to implement clinical pathways in an emergency department setting: Study protocol for a cluster randomized controlled trial. Implement Sci. 2013;8(55):55. https://doi.org/10.1186/1748-5908-8-55 PMid:23692634

24. Daniel MO, Rosentain AH. Professional communication and team collaboration. In: Hughes RG, editor. Patient Safety and Quality: An Evidence-Based Handbook for Nurses. Ch. 33. Rockville, MD: Agency for Healthcare Research and Quality; 2008.

25. World Health Organization. Regional Office for Europe. Transforming Health Services Delivery Towards People-centred Health Systems. World Health Organization; 2014. p. 14.

26. Bai J, Bai F, Zhu H, Xue D. The perceived and objectively measured effects of clinical pathways' implementation on medical care in China. PLoS One. 2018;3(5):e0196776. https:// doi.org/10.1371/journal.pone.0196776 PMid:29734350

27. Jabbour M, Newton AS, Johnson D, Curran JA. Defining barriers and enablers for clinical pathway implementation in complex clinical settings. Implement Sci. 2018;13(1):139 https://doi. org/10.1186/s13012-018-0832-8

PMid:30419942

28. Manullang, M. Dasar-Dasar Manajemen. Yogyakarta: Gajah Mada University; 2012.

29. Thakor MV, Joshi AW. Motivating salesperson customer orientation: Insights from the job characteristics model. J Bus Res. 2005;58(5):584-92. https://doi.org/10.1016/j. jbusres.2003.10.002

30. Mahaney CR, Lederer AL. The effect of intrinsic and extrinsic rewards for developers on information systems project success. Proj Manage J. 2006;37:42-54. https://doi. org/10.1177/875697280603700405

31. Altindis S. Job motivation and organizational commitment among the health professionals: A questionnaire survey. Afr J Bus Manag. 2011;5(21):8601-9. https://doi.org/10.5897/ ajbm11.1086

32. Sopiah. Perilaku Organisasional. Yogyakarta: Andi Press; 2008.

33. Chang $\mathrm{H}$, Chi $\mathrm{N}$, Miao $\mathrm{M}$. Testing the relationship between three-component organizational/occupational commitment and organizational occupational turnover intention using a non-recursive model. J Vocal Behav 2007;70:352-68. https:// doi.org/10.1016/j.jvb.2006.10.001

34. Meyer J, Becker T, Vandenberghe C. Employee commitment and motivation: A conceptual analysis and integrative model. J Appl Phys. 2004;89:991-1007. https://doi. org/10.1037/0021-9010.89.6.991

35. Johnson RE, Chang CH, Yang LQ. Commitment and motivation at work: The relevance of employee identity and regulatory focus. Acad Manag Rev. 2010;35:226-45. https://doi.org/10.5465/ amr.35.2.zok226 
36. Eby LT, Freeman DM, Rush MC, Lance CE. Motivational bases of affective organizational commitment: A partial test of an integrative theoretical model. J Occup Organ Psychol. 1999;72:463-83. https://doi.org/10.1348/096317999166798

37. DeSilva DAM, Yamao M. In: Choo PS, Hall SJ, Williams MJ, editors. The Involvement of Female Labor in Seafood Processing in Sri Lanka: Impact of Organizational Fairness, Organizational Commitment and Supervisor Evaluation on Employee Commitment. Penang, Malaysia: Global Symposium on Gender and Fisheries. Seventh Asian Fisheries Forum, 1-2 December, 2004; 2006. p. 103-14.

38. Pool S, Pool B. A management development model: Measuring organizational commitment and its impact on job satisfaction among executives in a learning organization. J Manag Dev. 2007;26:353-69. https://doi.org/10.1108/02621710710740101

39. Kim WG, Leong JK, Lee YK. Effect of service orientation on job satisfaction, organizational commitment, and intention of leaving in a casual dining chain restaurant. Hosp Manage. 2005;24:17193. https://doi.org/10.1016/j.ijhm.2004.05.004

40. Mowday RT, Steers RM, Porter LW. The measurement of organizational commitment. J Vocat Behav 1979;14:224-47.

41. McCabe TJ, Garavan TN. A Study of the drivers of commitment amongst nurses: The salience of training, development and career issues. J Eur Ind Train. 2008;32:528-68. https://doi. org/10.1108/03090590810899829

42. Hassaballa H, Payne J, Mcfolling S, Marder RJ. Enhancing clinical pathway placement. Qual Manag Health Care. 1998;7(1):13-7. https://doi.org/10.1097/00019514-199807010-00002 PMid:10344978

43. Mathieu JE, Zajac D. A review and meta-analysis of antecedents, correlates, and consequences of organizational commitment. Psychol Bull. 1990;108:171-94. https://doi. org/10.1037/0033-2909.108.2.171

44. Meyer JP, Stanley DJ, Herscovitch L, Topolnytsky L. Affective, continuance and normative commitment to the organization: A meta-analysis of ante-cedents, correlates and consequences. Journal of Vocat Behav 2002;61:20-52. https://doi.org/10.1006/ jvbe.2001.1842

45. Wang L, Bishop JW, Chen X, Scot KD. Collectivist orientation as a predictor of affective organizational commitment: A study conducted in china. Int J Organ Anal 2002;10:226-40. https:// doi.org/10.1108/eb028951

46. Hilaire WA, de la Robertie C. Correlates of affective commitment in organizational performance: Multi-level perspectives. Aust J Career Dev. 2018;27(1):3-8. https://doi. org/10.1177/1038416217744215

47. Ramlall S. A review of employee motivation theories and their implications for employee retention within organizations. J Am Acad Bus. 2004;5:52-64.

48. Maslach C, Leiter MP. Burnout and quality in a sped-up world. J Qual Partic. 2001;24:48-52.

49. Bjurling-Sjoberg P, Wadensten B, Poder U, Nordgren L, Jansson I. Factors affecting the implementation process of clinical pathways: A mixed method study within the context of
Swedish intensive care. J Eval Clin Pract. 2015;21(2):255-61. https://doi.org/10.1111/jep.12301

PMid:25678495

50. Mcconnell T, O'Halloran P, Porter S, Donnelly M. Systematic realist review of key factors affecting the successful implementation and sustainability of the Liverpool care pathway for the dying patient. Worldviews Evid Based Nurs. 2013;10(4):218-37. https://doi.org/10.1111/wvn.12003 PMid:23489967

51. Mamolen NL, Brenner PS. The impact of a burn wound education program and implementation of a clinical pathway on patient outcomes. J Burn Care Rehabil. 2000;21:440-5. https:// doi.org/10.1097/00004630-200021050-00010

PMid:11020052

52. Kate W, Masako T. Reframing Organizational Commitment within a Contemporary Careers Framework. New York: Cornell University; 2002.

53. Fischer F, Lange K, Klose K, Greiner W, Kraemer A. Barriers and strategies in guideline implementation a scoping review. Healthcare. 2016;4(3):36. https://doi.org/10.3390/ healthcare 4030036

54. Cluzeau FA, Littlejohns P, Grimshaw JM, Feder G, Moran SE. Development and application of a generic methodology to assess the quality of clinical guidelines. Int J Qual Health Care. 1999;11(1):21-8. https://doi.org/10.1093/intqhc/11.1.21 PMid:10411286

55. Doherty SR, Jones PD. Use of an "evidence-based implementation" strategy to implement evidence-based care of asthma into rural district hospital emergency departments. Rural Remote Health. 2006;6(1):529.

PMid: 16569189

56. Grimshaw JM, Shirran L, Thomas R, Mowatt G, Fraser C, Bero L, et al. Changing provider behaviour: An overview of systematic reviews of interventions. Med Care. 2001;39(8):II245. https://doi.org/10.1097/00005650-200108002-00002 PMid: 11583120

57. Grimshaw JM, Zwarenstein M, Tetroe JM, Godin G, Graham ID, Lemyre L, et al. Looking inside the black box: A theory-based process evaluation alongside a randomised controlled trial of printed educational materials (the Ontario printed educational message, OPEM) to improve referral and prescribing practices in primary care in Ontario, Canada. Implement Sci. 2007;2:38. https://doi.org/10.1186/1748-5908-2-38 PMid:18039362

58. Kinsman L, James E, Ham J. An interdisciplinary, evidencebased process of clinical pathway implementation increases pathway usage. Lippincotts Case Manag. 2004;9(4):184-96. https://doi.org/10.1097/00129234-200407000-00006 PMid: 15273604

59. Pugh-Bernard A, Nickels S, Melendez J, Shawkat J, Rolison E, Swanson A, et al. A strategy for the renovation of a clinical pathways program. Pediatr Qual Saf. 2019;4(3):e178. https:// doi.org/10.1097/pq9.0000000000000178 